\title{
ESTABLISHING AN EFFECTIVE INTERNAL CONTROL SYSTEM FOR FRAUD PREVENTION: A STRUCTURED LITERATURE REVIEW
}

\author{
Nor Hafizah Abdul Rahman ${ }^{1}$ Noradiva Hamzah ${ }^{2}$, Adibah Jamaluddin ${ }^{3}$ \\ and Khairul Azman Aziz ${ }^{4}$ \\ ${ }^{1}$ Faculty of Accountancy, Universiti Teknologi MARA, Malaysia \\ Email: hafizah587@uitm.edu.my \\ ${ }^{2}$ School of Accounting, Faculty of Economics and Management, \\ Universiti Kebangsaan Malaysia \\ Email: adibz@ukm.edu.my \\ ${ }^{3}$ Faculty of Accountancy, Universiti Teknologi MARA, Malaysia \\ Email: adibahj@uitm.edu.my \\ ${ }^{4}$ School of Accounting, Faculty of Economics and Management, \\ Universiti Kebangsaan Malaysia \\ Email: khairul.aziz@ukm.edu.my
}

\begin{abstract}
This study presents a structured literature review of an effective internal control system. The purpose of this study is to explore and review articles in the field of internal control effectiveness using the Guthrie, Ricceri, and Dumay (2012)'s framework. The literature indicates that effective internal control can reasonably reduce business risks and prevent occurrence of fraud. This paper reports findings, based on articles on internal control effectiveness published from 2000 to 2018. The review process was conducted in five stages, (1) formulation of research objectives to determine the classifications, boundaries, and definition; (2) the selection of journals; (3) the examination of the title and abstract of selected articles; (4) pilot test and adapted classification and (5) the classification to establish a range of descriptive statistics in order to understand the patterns emerging from the reviewed articles. The finding provide a basis for several aspects of future research of internal control effectiveness in assessing business risks for prevention of fraud.
\end{abstract}

Keywords: structured literature review, internal control, fraud prevention

ARTICLE INFO

Article History:

Received: 15 July 2019

Accepted: 24 October 2019

Published: 31 December 2019 


\section{INTRODUCTION}

The KPMG ${ }^{1}$ Malaysia Fraud, Bribery and Corruption Survey (2013) revealed poor internal control as the most important factor contributing to the occurrence of major frauds in Malaysia. This is further supported by studies done by the Association of Certified Fraud Examiners (ACFE) Global Fraud Survey (2018) which revealed that small businesses around the globe faced similar problems with more than $42 \%$ of organizations with poor internal control have fewer than 100 employees. Poor, inadequate and insufficient controls provide an attractive inducement to prospective perpetrators since it reflects that the management is not serious in handling the problem (Voon, Voon, \& Puah, 2008). As a starting point, this paper considers the review of previous studies on internal control by Schneider, Gramling, Hermanson and Ye (2009) on internal control reporting subsequent to Sarbanes-Oxley Act (SOX) sections 302 and 404 which are US dominated. However, SOX is not mandatory in some countries and thereby is not subject to the SOX audit or is not required to produce the SOX management report (Brown, Pott, \& Wömpener, 2014). Meanwhile, another review by Chalmers, Hay, and Khlif (2018) merely focused on the determinants of internal control quality and its economic consequences for stakeholders. Therefore, this paper extends those studies by conducting an empirical research of internal control effectiveness using a structured literature review (SLR) methodology developed by Guthrie et al. (2012). This paper is organised as follows: Section 2 defines internal control and summarises studies in the internal control field. Section 3 outlines the structured literature review methodology and Section 4 discusses the issues associated with the field of internal control effectiveness and how weak internal control is associated with fraud.

\section{DEFINING INTERNAL CONTROL}

The Committee on Auditing Procedure of the American Institute of Certified Public Accountants (AICPA) first introduced the definition of internal control in 1949 as "the plan of organization and all of the coordinate methods and measures adopted within a business to safeguard its assets, check the accuracy and reliability of its accounting data, promote

1 KPMG is an internationally known multinational professional services network, and one of the Big Four accounting organisations. The name KPMG stands for "Klynveld Peat Marwick Goerdeler". It was chosen when KMG (Klynveld Main Goerdeler) merged with Peat Marwicj in 1987. 
operational efficiency, and encourage adherence to prescribed managerial policies". This definition of internal control was refined in 1963 to "the plan of organization and all of the coordinate methods and measures adopted within a business to safeguard its assets, check the accuracy and reliability of its accounting data, promote operational efficiency, and encourage adherence to prescribed managerial policy' (Bower \& Schlosser, 1965). The Committee of Sponsoring Organisations of the Treadway Commission (COSO) (2013) define internal control as “a process, effected by an entity's board of directors, management, and other personnel, designed to provide reasonable assurance regarding the achievement of objectives relating to operations, reporting, and compliance". This definition of internal control reflects certain fundamental concepts where internal control is a process and it is affected by people and not merely policy manuals and forms at every level of the organization.

Internal control has undergone major reappraisals and changes during the last decade. These changes began in 1988 when the AICPA issued SAS No. 55, which describes internal control in terms of its three major components: control environments, accounting systems, and control procedures. Four years later, the Committee of Sponsoring Organizations (COSO) issued the Internal Control Integrated Framework, in which the characteristics of internal control include five components: control environments, control activities, risk assessment, information and communication, and monitoring activities (COSO, 2013). These interrelated components must be present and function properly in order to have adequate and effective internal control systems (Rezaee, 1995).

A review of literature reveals a number of studies focusing on internal control which can be grouped in several broad categories, which are internal control weaknesses (Ashbaugh-Skaife, Collins, Kinney, \& Lafond, 2009; Doyle, Ge, \& McVay, 2007), internal control reporting disclosure (Deumes \& Knechel, 2008; Hermanson, 2000) and internal control effectiveness (Amudo \& Inanga, 2009; Jokipii, 2009; Leng, 2011). In addition, the review also reveals that there are very few studies focusing on internal control effectiveness as a mechanism for fraud prevention (Seetharaman, Senthilvelmurugan, \& Periyanayagam, 2004). Therefore, using a SLR methodology, this paper will address the following questions: 1) How does research for inquiring into internal control effectiveness evolve? and 2) What is the future for internal control research? 


\section{STRUCTURED LITERATURE REVIEW METHODOLOGY}

In this section, the methodology used for conducting a SLR are outlined. In producing a quality literature review, Massaro, Dumay, and Guthrie (2016) defined SLR as "a method for studying a corpus of scholarly literature, to develop insights, critical reflections, future research paths and research questions". They also proposed a literature review field which shows that SLR follows rigid rules whereas traditional literature review is adjacent to no rules. In accounting research, the SLR method helps accounting scholars to develop a different approach to a literature review (Massaro et al., 2016), which is the focus of this study. The review process was conducted in five stages (1) formulation of research objectives to determine the classifications, boundaries, and definition; (2) the selection of journals; (3) examination of the title and abstract of all selected articles; (4) pilot test and adapted classification and (5) the classification to establish a range of descriptive statistics in order to understand the patterns emerging from the reviewed articles.

\section{Literature Search}

The journals were selected from the year 2000 to 2018 based on Google Scholar's h5-index ranking of "Accounting and Taxation" journals. Journals were also selected from the Scimago Journal and Country Ranking with a 1 to 3 h-index ranking (Table 1). The purpose is to ensure the reliability and validity of the journal articles that will be examined.

The literature search began by examining high impact internal control studies as evidenced by the number of citations the article received. The article searching process from all journals was done through the Harzing software with a minimum of 15 citations per year and using a keyword search: 1) internal control and 2) internal control AND effectiveness from the database from the selected journals. This includes empirical research, conceptual framework, theoretical, literature review and commentary articles that provide insight into the internal control. Considering the recent issues in the internal control study, the raw citation index was also used to include the latest articles that have been cited. 
Next, the journal articles were analysed using the NVivo software which helps in constructing the matrix table for a literature review. The Mendeley software was also used in analysing, citing and the writing process of the literature review.

Table 1: Selected Journal and Code

\begin{tabular}{lcccc}
\hline \multicolumn{1}{c}{ Journal name } & $\begin{array}{c}\text { Journal } \\
\text { code }\end{array}$ & $\begin{array}{c}\text { SJR } \\
\mathbf{2 0 1 7}\end{array}$ & $\begin{array}{c}\text { Google } \\
\text { H5-index }\end{array}$ & $\begin{array}{c}\text { Total } \\
\text { articles }\end{array}$ \\
\hline The Accounting Review & AR & 3.946 & 65 & 34 \\
Journal of Accounting and Economics & JAE & 6.975 & 54 & 13 \\
Journal of Accounting Research & JAR & 6.967 & 51 & 8 \\
Contemporary Accounting Research & CAR & 2.604 & 48 & 19 \\
Review of Accounting Studies & RAS & 2.757 & 42 & 4 \\
AUDITING: A Journal of Practice \& & AJPT & n/a & 36 & 24 \\
Theory & & & & \\
Accounting, Organisation and Society & AOS & 1.771 & 37 & - \\
Management Accounting Research & MAR & 1.426 & 34 & 3 \\
Accounting, Auditing \& Accountability & AAAJ & 2.187 & 37 & 4 \\
Journal & & & & \\
Critical Perspectives on Accounting & CPA & 1.773 & 37 & - \\
Accounting Horizons & AH & 0.720 & 30 & 15 \\
Journal of Accounting and Public Policy & JAPP & 0.910 & 30 & 9 \\
Journal of Business Finance \&Accounting & JBFA & 0.910 & 25 & 2 \\
European Accounting Review & EAR & 0.902 & 27 & - \\
Accounting \& Finance & AF & 0.384 & 26 & 5 \\
The British Accounting Review & BAR & 0.986 & 30 & 1 \\
Accounting and Business Research & ABR & 0.970 & 26 & 1 \\
International Journal of Accounting & IJAIS & 0.399 & n/a & 7 \\
Information System & & & & \\
\hline Sors & & & & \\
\hline
\end{tabular}

Source: Guthrie et al (2012), Dumay (2014), Jamaluddin (2015)

Note: The Google scholar metrics was last retrieved on June 2018. The SJR indicator measures the scientific influence of the average article in a journal. It expresses how central to the global scientific discussion an average article of the journal is. The h5-index is the h-index for articles published in the last five complete years.

Table 2 presents the articles selected. These article were selected by examining the full article in determining whether they meet the boundaries as determined by the study and to minimise the risk of missing relevant articles. As a result, 63 articles were downloaded in the form of pdf versions and stored in Mendeley database with referencing details. However, some of the articles could not be retrieved due to the university's subscription issues. 


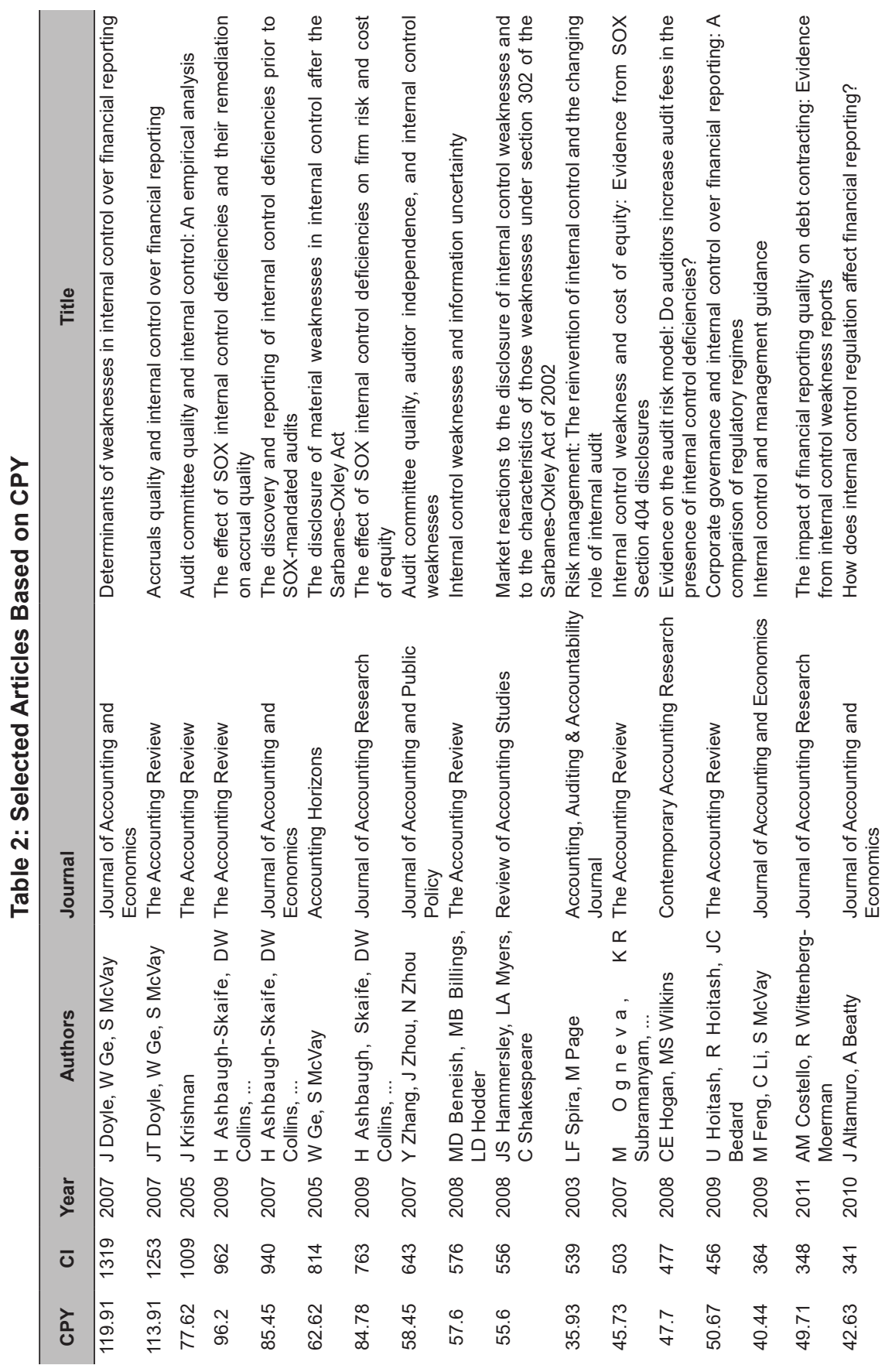




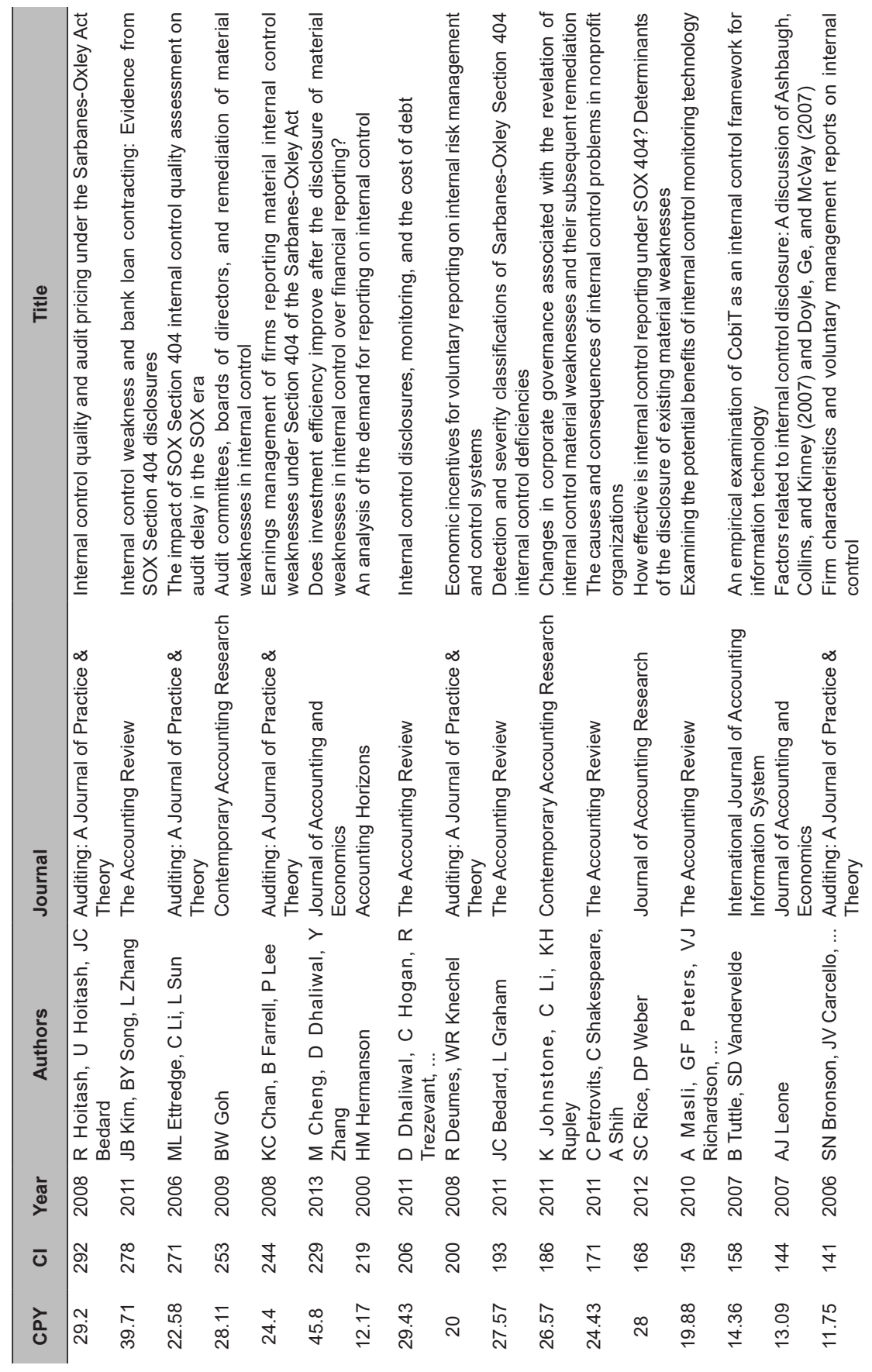




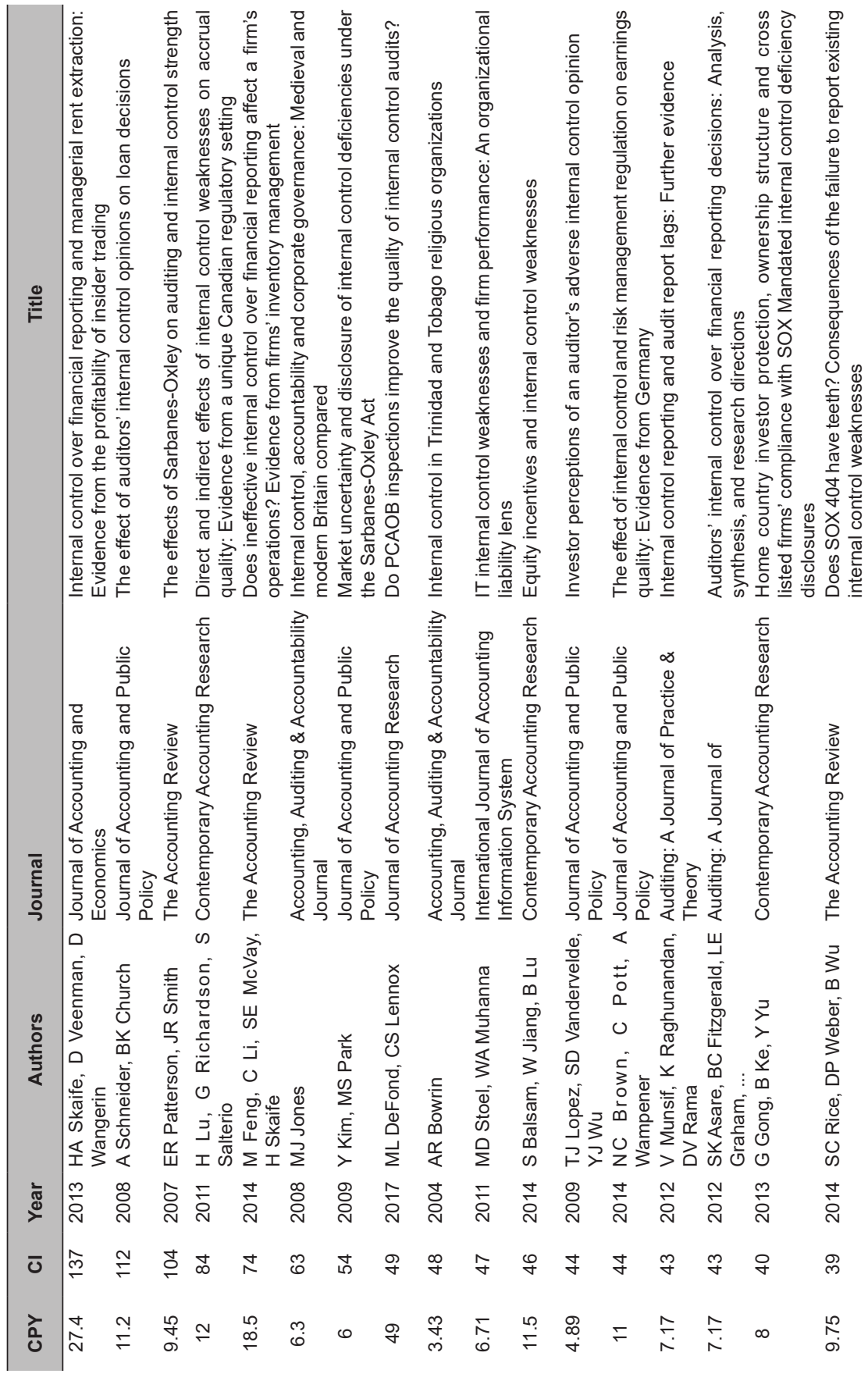




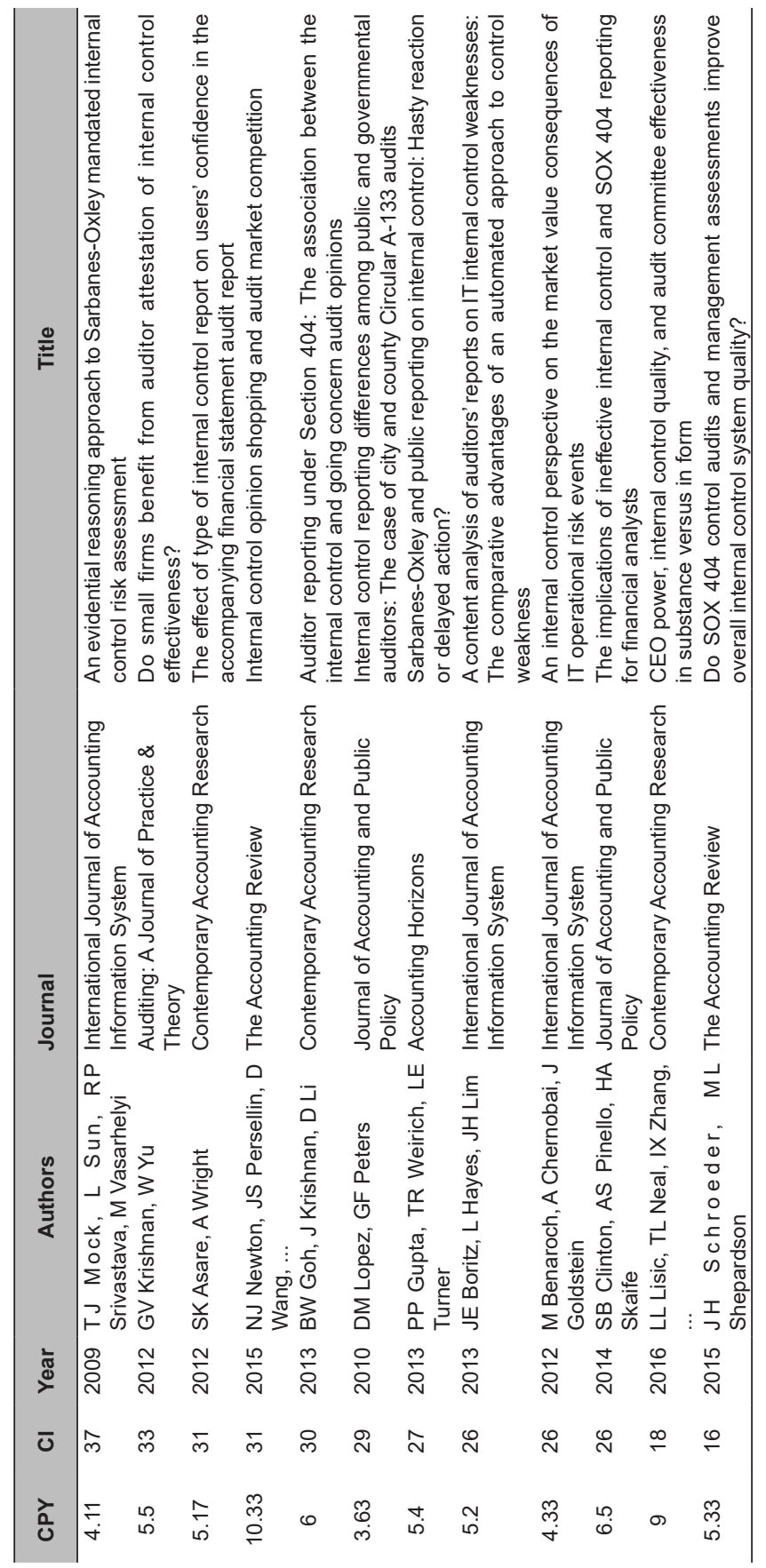




\section{Development and Refining the Analytical Framework}

Based on the analytical framework was developed by adopting the analytical criteria based on jurisdiction, organisation focus, location, research method, and framework/model (Guthrie et al., 2012).

Table 3: Classification System for Analysing Articles

\section{A. Jurisdiction}

A1. Supra-national - international - comparative - general

A1.1. Supra-national - international - comparative - industry

A1.2. Supra-national - international - comparative - organisational

A2. National - general

A2.1. National - industry

A2.2. National - organizational

A3. One organisation

\section{B. Organisational focus}

B1. Publicly listed

B2. Private - SMEs

B3. Private - others

B4. Public sector

B5. Not for profit

B6. General - other

\section{Location}

C1. North America

C2. Australasia

C3. Asia

C4. United Kingdom

C5. European union

C6. Others

C7. None specified

\section{Focus of internal control studies}

D1. Internal control quality 
D2. Internal control disclosure

D3. Internal control reporting

D4. Internal control weaknesses

D5. Internal control effectiveness

D6. Internal control - others

\section{E. Research method}

E1. Case/field study/interviews

E2. Content analysis/historical analysis

E3. Survey/questionnaire/other empirical

E4. Theoretical/literature review/normative/commentary

E5. Multi-method - interviews and questionnaires

\section{F. Framework and models}

F0. No model proposed

F1.0 Applies or considers previous models

F1.1 Proposed new model

Source: Adapt from Guthrie, Ricceri and Dumay (2012); Broadbent and Guthrie (2008)

\section{Coding and Data Analysis}

The NVivo 11 Pro software was used to code and analyse the articles. Nvivo is a qualitative data analysis software (QDAS) that "incorporates features such as aggregating codes, auto-coding based on set criteria and developing common word counts" as suggested by Massaro et al. (2016). The software facilitates common qualitative techniques for organizing and analysing the articles for a structured data which is not possible by only using the spreadsheet.

Throughout the SLR analysis, the coding and nodes for the articles were discussed among the researchers. The coding was followed as per suggested in the jurisdiction as well as title, author, year, research objective, methodology, and findings. This helps the software to construct a framework matrix for the literature review as in Figure 1: 


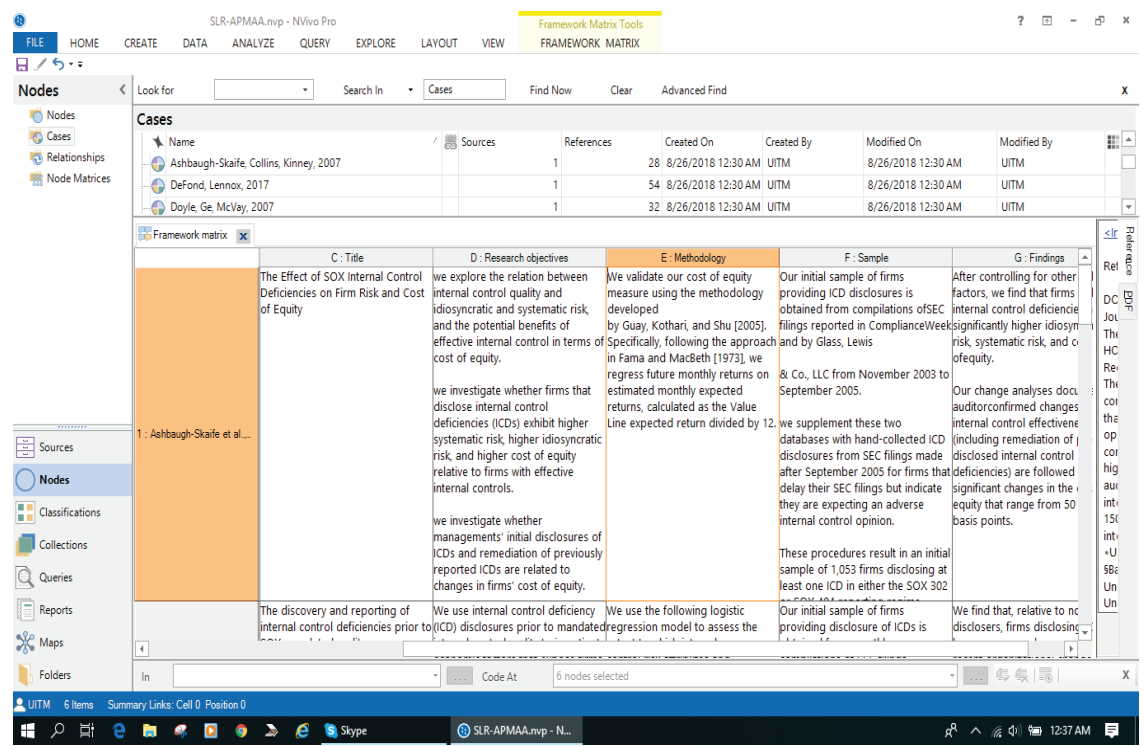

Figure 1: Framework Matrix For Literature Review

\section{THE ANALYSIS OF STRUCTURE LITERATURE REVIEW}

This section presents the meta-analysis of the selected articles to answer the question: How does research for inquiring internal control studies evolve? First, analysis based on journal, publication years and the dominant author is presented, followed by jurisdiction, organisational focus, location, the focus of internal control studies, research method and analysis based on framework and model.

\section{Journal}

The analysis shows that 63 articles represent the sample of internal control studies. This SLR found that The Accounting Review, AUDITING: A Journal of Practice \& Theory and Contemporary Accounting Research is the leading journal publishing research on internal control and they are highly cited (Table 2). Meanwhile, other journals publish this research area but consider more interdisciplinary matters. 


\section{Publication Year}

Figure 2 summarises the publication year of the sample articles. A smaller number of articles were published from 2000 to 2006 showing that studies on internal control are scarce. However, internal control studies began to gain the interest of the researchers as a result of the Enron case during 2000 as evidenced by the growing trend of selected articles (Figure 2). More importantly, the highest number of selected articles were published during 2007 - 2008 and were related to internal control weaknesses that represent ineffective internal controls.

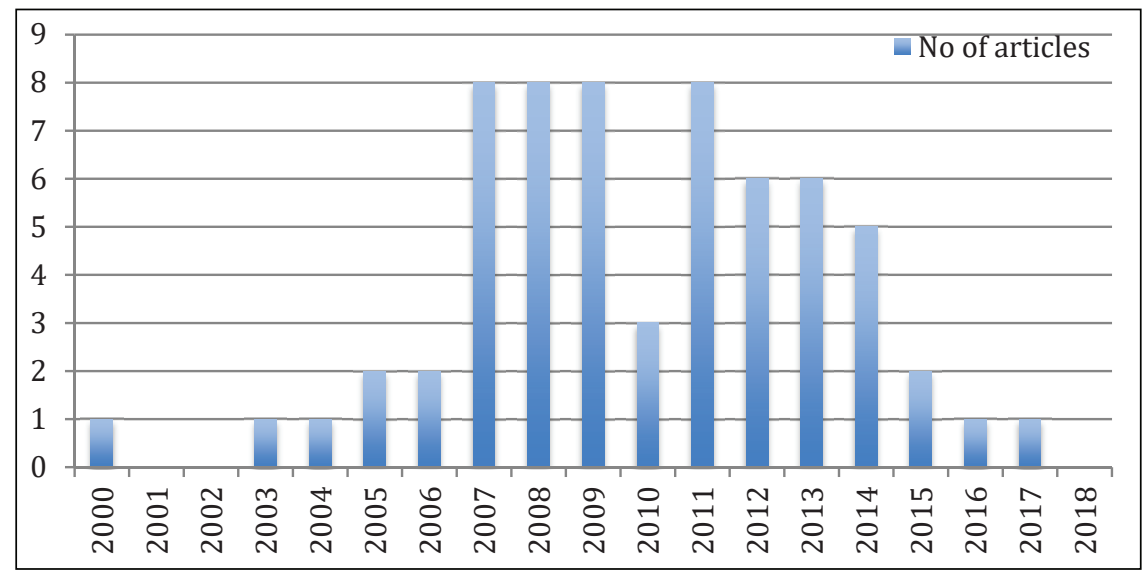

Figure 2: Number of Selected Articles Published in 2000-2018

\section{Dominant Author}

The study found that 121 authors wrote the selected 63 articles (Table 2). Of these, only 18 published more than one article. As Table 2, AshbaughSkaife, McVay, and Li are the dominant authors in the sample publishing at least 5 articles each. Therefore, they are considered the key-players in the area of internal control studies particularly internal control weaknesses.

\section{Jurisdiction}

Based on Guthire et al. (2012), this criterion is divided into (A1.) general paper that does not have an empirical base such as broad literature review, (A2.) paper that focusses on nations, regions, networks, alliances 
and papers that refer to organisational settings (A1.1; A1.2; A2.1; A2.2; A3). Within the papers that refer to an organisational setting there were: A1.1 International - Industry which included papers based on evidence from specific industries belonging to specific countries; A1.2 International - Organisation which included papers that used evidence from one or more organisations belonging to either multiple industries or multiple countries; A2.1 National - Industry which included papers based on a specific industry belonging to one single country; A2.2 National - Organisational which included papers that used evidence from organisations belonging to a single country; and A3 One organisation which included papers based on a specific organisation.

Table 4: Jurisdiction

\begin{tabular}{lcc}
\hline & Total & $\%$ \\
\hline A1. Supra-national - international - comparative - general & 3 & $5 \%$ \\
A1.1. Supra-national - international - comparative - industry & 0 & - \\
A1.2. Supra-national - international - comparative - organisational & 0 & - \\
A2. National - general & 52 & $82 \%$ \\
A2.1. National - industry & 3 & $5 \%$ \\
A2.2. National - organizational & 2 & $3 \%$ \\
A3. One organisation & 3 & $5 \%$ \\
\hline
\end{tabular}

As in Table 4 above, the study shows that the jurisdiction of the papers emerged. Interestingly, the study found that the majority of the papers take a top down approach, which examine from a general perspective (Guthrie et al., 2012). This highlights how most internal control studies try to generalise findings across all organisations as opposed to looking at the practice of internal control from within an organisation. Only $13 \%$ of the papers examine internal control at the industry and organisational level.

\section{Organisational Focus}

The criterion for organisational focus is divided into six different elements as shown in the following Table 5. However, other types of organisations that did not fit the five types of organisations listed below, or that had no organisational focus were classified as B6. General - others. 
Table 5: Organisational Focus

\begin{tabular}{lcc} 
& Total & $\%$ \\
\hline B1. Publicly listed & 50 & $79 \%$ \\
B2. Private - SMEs & 0 & - \\
B3. Private - others & 0 & - \\
B4. Public sector & 0 & - \\
B5. Not for profit & 2 & $3 \%$ \\
B6. General - others & 11 & $18 \%$ \\
\hline & 63 & $100 \%$ \\
\hline
\end{tabular}

Table 5 highlights the organisational focus on selected articles. The most commonly researched were public listed companies due to easy access to the data and research sites. Furthermore, the dominance of public listed companies may be due to the focus on internal control studies highlighted that the importance of internal control reporting under US regulations i.e. Sarbanes-Oxley Act 2002 since most of the paper location identified were in North America. In contrast none of the articles focus on private companies including SMEs and the public sector may be due to voluntary disclosure. However, two papers reported on non-profit organisations and several from general - others due to it being either a discussion or commentary paper. Therefore, there is limited evidence on internal control studies on private companies especially SMEs and the public sector. 


\section{Location}

Table 6: Location

\begin{tabular}{lcc}
\hline & Total & $\%$ \\
\hline C1. North America & 54 & $85 \%$ \\
C2. Australasia & 0 & - \\
C3. Asia & 0 & - \\
C4. United Kingdom & 1 & $2 \%$ \\
C5. European union & 2 & $3 \%$ \\
C6. Others & 1 & $2 \%$ \\
C7. None specified & 5 & $8 \%$ \\
\hline & 63 & $100 \%$ \\
\hline
\end{tabular}

This criterion refers to the geographical location of the research undertaken. The percentage shows studies undertaken in the US emerging from the Enron case in the year 2000. As a result, more studies on internal control based on the Sarbanes-Oxley Act - SOX reported on internal control Section 404 and 302 in the US. The remaining articles came from other geographical areas, the UK, EU, and others. Surprisingly, none of the studies were carried out in Australasia and Asia.

\section{Focus of Internal Control Studies}

As for the focus of internal control studies, there were six specific elements used: D1. Internal control quality; D2. Internal control disclosure; D3. Internal control reporting; D4. Internal control weaknesses; D5. Internal control effectiveness; and all the articles that could not be coded into the former classifications were coded as D6. Internal control - others.

Table 7: Focus of Internal Control Studies

\begin{tabular}{lcc}
\hline & Total & $\%$ \\
\hline D1. Internal control quality & 7 & $11 \%$ \\
D2. Internal control disclosure & 3 & $5 \%$ \\
D3. Internal control reporting & 9 & $14 \%$ \\
D4. Internal control weaknesses & 29 & $46 \%$ \\
D5. Internal control effectiveness & 5 & $8 \%$ \\
D6. Internal control - others & 10 & $16 \%$ \\
\hline & 63 & $100 \%$ \\
\hline
\end{tabular}


Table 7 represents the focus of the internal control studies. The most popular focus was internal control weaknesses which had 29 papers. Since most of the papers reported on internal control in North America discussed the Sarbanes-Oxley Act 2002 which was mandatory for all publicly listed companies, therefore, the motivation was derived to investigate the content of the SOX404 and SOX302 whereby material weaknesses in internal control must be disclosed in auditors' and management reports (Cheng, Dhaliwal, $\&$ Zhang, 2013). In addition, the other papers examined the determinants of material weaknesses in internal control over financial reporting (Doyle et al., 2007) as well as the association between corporate governance and disclosure of material weaknesses in internal control reporting (Hoitash, Hoitash, \& Bedard, 2009). Therefore, the study urged that internal control weaknesses reflects ineffectiveness of internal control systems.

\section{Research Method}

Table 8 summarises the research methods employed in selecting the articles. Consistent with Guthrie et al. (2012), the study divided the selection of the articles based on normative and empirical attributes. Normative articles (E4) are conceptual, theoretical, literature review and/or commentary article, providing frameworks or models aimed at explaining phenomenon under observation. Some research papers proved problematic to classify into an exact element as two or three research methods may have been used. In such cases, the articles were coded based on the dominant research method used for primary data analysis.

Table 8: Research Method

\begin{tabular}{lcc}
\hline & Total & $\%$ \\
\hline E1. Case/field study/interviews & 1 & $2 \%$ \\
E2. Content analysis/historical analysis & 50 & $79 \%$ \\
E3. Survey/questionnaire/other empirical & 5 & $8 \%$ \\
E4. Theoretical/literature review/normative/commentary & 7 & $11 \%$ \\
E5. Multi-method - interviews and questionnaires & 0 & - \\
\hline
\end{tabular}

As shown in Table 8, the study identified that most articles were based on content analysis and historical analysis. This is due to the sample of the studies being collected and obtained from a compilation of SEC fillings 
reported in the Compliance Week, SOX audit opinion from Audit Analytics, financial data from Compustat.

\section{Framework and Model Apply in Research}

Table 9: Framework and Models

\begin{tabular}{lcc}
\hline & Total & $\%$ \\
\hline F0. No model proposed & 4 & $6 \%$ \\
F1.0 Applies or considers previous models & 53 & $84 \%$ \\
F1.1 Proposed new model & 6 & $10 \%$ \\
\hline
\end{tabular}

Table 9 highlights the framework or model used in the selected articles. Using Nvivo11, the study analysed the use of a framework or model in the selected articles. The study found that most articles applied or considered previous models. This criterion may be a result from the research methods used as mentioned earlier based on content analysis and historical analysis. Compared to the other two which are 1) no model proposed resulted from commentary articles and broad discussion on literature review and 2) proposed new model includes those that extend or revise the previous framework. Thus, the study indicates that proposing a new framework or model might have a significant impact because the framework informs the way the practice should be, which can be applied in other studies for rigour or to be further improved.

\section{SUMMARY OF FINDINGS FROM SELECTED ARTICLES}

Leading on from the SLR above, the following discussion on main findings from selected articles to answer the question: What is the future for internal control research?

\section{Internal Control Weaknesses}

Since most of the papers reported studies on internal control weaknesses was at North America and discussed the SLR above on the Sarbanes-Oxley Act 2002 which was mandatory to all publicly listed 
companies therefore, the motivation was derived to investigate the content of SOX404 and SOX302. Studies on internal control weaknesses emerged due to the collapse of several large corporations such as Enron and World Com. One of the after effects of these scandals was the Sarbanes-Oxley Act 2002 (SOX) designed with the goal of improving financial reporting and restoring investor confidence in publicly traded firms (Donaldson, 2005; in Singer \& You, 2011). Singer and You (2011) suggested that Section 404 of SOX helped to achieve the main goal of the act, protecting investors and restoring their confidence in the stock market by improving the accuracy and reliability of corporate disclosure. Further studies by Clinton, Pinello and Skaife (2014) investigated the implications of material weaknesses in internal control and SOX 404 required reporting of such for financial analysts because analysts are important intermediaries in the U.S. capital markets and it is not known whether analysts' forecast or coverage decisions are affected by firms internal control problems or reporting, respectively. They found that based on their empirical tests analysts provide less accurate forecasts and there is greater forecast dispersion for firms with ineffective internal control.

Ashbaugh-Skaife et al. (2009) examined firms that reported internal control deficiencies (ICDs) under Section 404 of the SOX. They found that those firms had a lower quality of accruals and firms whose auditors confirmed remediation of those deficiencies exhibit an increase in their accrual quality. Gong, Ke and Yu (2013) investigated home country investor protection and ownership structure on the SOX-mandated ICDs disclosures by foreign firms listed on the U.S. stock exchange. They found that for cross-listed firm domiciled in weak investor protection countries, firms whose managers control their firms and have voting rights in excess of cash flow rights are more likely to misreport internal control deficiency and also managers who have the ability and incentive to expropriate outside minority shareholders are reluctant to disclose ICDs in order to protect their private control benefits. Another study by Balsam and Lu (2014) examine whether the monetary incentives associated with equity ownership induce managers to maintain strong internal control and found that the likelihood of a material weakness in internal control decreases with increases in equity incentives.

Another study by Chang and Sun (2010) found that the market valuation of earnings surprises is significantly higher for firms which disclose stronger 
corporate governance functions, in which the internal control forms part of corporate governance. They also found that the effectiveness of corporate governance in monitoring earnings management is improved after the mandated disclosure. It shows that the quality of accounting earnings is increased after the SOX's mandated disclosure, which strengthens the link between financial reporting and corporate governance functions. Doyle, Ge, and McVay (2007) discovered that material weaknesses are generally associated with poorly estimated accruals that are not realised as cash flows when they examine the relationship between accruals quality and internal controls. Furthermore, they found that this relation between weak internal controls and lower accruals quality is driven by weakness disclosures that relate to overall company-level controls. The management will face greater incentives to discover and report internal control weaknesses when the firms are subjected to greater monitoring by the stakeholders and when those stakeholders have greater incentives to initiate litigation if the firms' financial reporting process is deemed to be deficient. The managers of firms with more concentrated ownership face greater incentives to disclose internal control deficiencies (Ashbaugh-Skaife, Collins, \& Kinney, 2007). Another study done by Doyle, Ge and McVay (2007) found that the firms that disclosed material weaknesses in internal control are more likely indicate the firms that are smaller in size, experienced financial difficulties and were thus less profitable, more complex, growing rapidly, or undergoing restructuring.

SOX Section 404 provides a unique setting to examine audit committee oversight that companies required to disclose their auditors' opinions on the effectiveness of their internal controls, which are designed to provide reasonable assurance that financial statements are prepared in compliance with U.S. GAAP. Such disclosure suggested that internal control effectiveness is a valid indicator of the quality of a firm's financial reporting. One of the primary responsibilities of the audit committee is to oversee the company's internal control (Hoitash et al., 2009). Lisic, Neal and Zhang (2016) provide empirical evidence that the substantive effectiveness of audit committee in monitoring financial reporting is contingent on top management power. On the other hand, when top management power is low, audit committee financial expertise is negatively associated with the incidence of internal control weaknesses. In addition, Schroeder and Shepardson (2015) found internal control audit initially provide internal control quality benefits. Furthermore, Defond and Lennox (2017) test 
whether PCAOB inspections help remediate auditors' deficiencies in detecting and reporting internal control weaknesses. They found that auditors respond by increasing their issuance of adverse internal control audit opinions and suggested that PCAOB inspections improve the quality of internal control audit through their ability to remediate deficiencies in auditors' internal control audit procedures.

It is widely recognized that material internal control weaknesses give management the flexibility to manipulate financial reporting to conceal their expropriation activities. Furthermore, those studies should be of interest to regulators who wish to identify non-compliant firms for closer supervision, investors who wish to identify red flags for poor financial disclosure quality. In addition, studies in non-US jurisdiction open opportunities to explore the determinants and consequences of internal control in other jurisdictions.

\section{Internal Control Effectiveness}

Internal control effectiveness was defined on the basis of how well three objectives of internal control in the frameworks are met by the firms which are; first, the efficiency and effectiveness of activities, second, the reliability and timeliness of financial and management information, and lastly, the compliance with applicable laws and regulations (Agbejule \& Jokipii, 2009; COSO, 2013). Due to the collapse of several large corporations such as Enron and WorldCom, the introduction of the Sarbanes-Oxley Act 2002 has clearly shown that not only must the internal control system be presented and clearly defined, but also the means of implementing the internal control system as well as assessing their effectiveness.

The Sarbanes-Oxley Act (SOX) mandates management evaluation and independent audits of internal control effectiveness. The mandate is costly to the companies but may yield benefits through lower information risks that translates into lower cost of equity (Ashbaugh-Skaife et al., 2009). Section 404 of the landmark Sarbanes-Oxley Act (SOX) requires public companies to report the effectiveness of their internal control systems and requires auditors to verify management's reports as well as to provide their own reports on the effectiveness of the internal control systems $(\mathrm{Li}$, Lim, \& Wang, 2007). In addition, in Bierstaker, Janvrin and Lowe (2007), Section 404 of the Sarbanes-Oxley Act of 2002 (SOX) mandates that all 
publicly traded companies include management's assessment of internal control effectiveness over financial reporting in their annual report and that independent auditors attest to management's evaluation of internal control. Lopez, Vandervelde and $\mathrm{Wu}$ (2009) suggested that an adverse audit opinion on internal control over financial reporting provides incremental value-relevant information to investors beyond that contained in the financial statement audit opinion alone. Skaife, Veenman and Wangerin (2013) examine the association between ineffective internal control over financial reporting and the profitability of insider trading and found that insider trading profitability is even greater when insiders are more likely to act in their own self-interest as indicated by auditors' weak "tone at the top" adverse internal control opinions.

On the other hand, risk management efficiency is a part of internal control effectiveness that it is very important to the firm. Risk management efficiency should be informed to the shareholders. The clear and sufficient accounting policies can bring appropriate internal control effectiveness. Therefore, risk management efficiency is purported to help firms' update rules, a standard of work, guidance, and especially a quality of compliance (COSO, 2004). However, organizations using a weaker risk management process focused on control and compliance experience with more difficulty. Many studies reveal that firms with high accounting risks, more financial distress, and poor accruals quality are more likely to receive an adverse opinion on internal control effectiveness (Ashbaugh-Skaife et al., 2007; Doyle et al., 2007). Internal control effectiveness is strongly significant on the reliability of financial reporting because internal control is essential for corporate governance statement for the firms (Ashbaugh-Skaife et al., 2007).

While business firms require ongoing changes in the organizations' activities, they also provide internal control effectiveness thoroughly understanding the way continuous monitoring adequacy is because continuous monitoring ensures that firms are subjected to operational effectiveness, reliability of financial reporting and regulatory compliance (Abbas \& Iqbal, 2012). Furthermore, monitoring of the major risks should be a part of the daily activities of all organizations along with the periodic evaluations. The top management must provide a control culture, regularly assessing the associated risks, requiring the implementation of effective and efficient control activities with segregation of duties of its employees, 
and reliable information at all levels to align with the short and long-term objectives of the organizations.

\section{Internal Control and Fraud}

The statement on Auditing Standards (SAS) No. 82: Consideration of fraud in a Financial Statement Audit has highlighted the increasing importance of internal controls in auditors' fraud risk assessments. This standard requires auditors to assess the risk of fraud on every audit and encourages auditors to consider both the internal control system and management's attitude towards the controls.

A review of the literature reveals a number of studies focusing on fraud and internal control (Barra, 2010; Murphy \& Tibbs, 2010). Barra (2010) investigated the influence of the penalties or the tightened controls on reducing fraud in a firm. The penalties imposed by the SOX 2002 on firm executives are fined up to $\$ 5$ million and/or imprisonment up to 20 years. At the same time, this legislation requires firms to tighten their internal control over financial reporting. Barra (2010) found that utilizing internal control in the form of separation of duties does increase an employee's cost of committing fraud, which means an employee will require a greater gain from his efforts than without separation of duties. Furthermore, the study also found that high penalties imposed on top management by the SOX 2002 were more effective at deterring managerial employees from committing fraud than other instituting types of internal control.

\section{CONCLUSION}

The paper argues that SLR has helped in identifying the key player in the field, understanding their contributions and uncovering the future of internal control studies. Thus, this paper addresses the gap by empirically analysing the trend of internal control weaknesses and internal control effectiveness in terms of financial reporting quality. Moreover, future studies in examining the determinants of internal control quality should investigates its internal and external factors. In addition, the review revealed that there is limited empirical research on internal control as a fraud prevention mechanism in an organization. Specifically, the limited evidence of internal control effectiveness with connecting to fraud motivated the direction of this paper. 


\section{REFERENCES}

ACFE. (2018). Global Fraud Study: Report to the nations on occupational fraud and abuse. Retrieved from https://www.acfe.com/rttn/docs/20 18-report-tonations.pdf.

Abbas, Q., \& Iqbal, J. (2012). Internal control system: Analyzing theoretical perspective and practices. Middle-East Journal of Scientific Research, 12(4), 530-538.

Agbejule, A., \& Jokipii, A. (2009). Strategy, control activities, monitoring and effectiveness. Managerial Auditing Journal, 24(6), 500-522.

Amudo, A., \& Inanga, E. L. (2009). Evaluation of internal control systems: A case study from Uganda. International Research Journal of Finance and Economics, 27(1), 124-144.

Ashbaugh-Skaife, H., Collins, D. W., Kinney Jr, W. R., \& Lafond, R. (2009). The effect of SOX internal control deficiencies on firm risk and cost of equity. Journal of Accounting Research, 47(1), 1-43.

Ashbaugh-Skaife, H., Collins, D. W., \& Kinney, W. R. (2007). The discovery and reporting of internal control deficiencies prior to SOX-mandated audits. Journal of Accounting and Economics, 44(1-2), 166-192.

Balsam, S., Jiang, W., \& Lu, B. (2014). Equity incentives and internal control weaknesses. Contemporary Accounting Research, 31(1), 178-201.

Barra, R. A. (2010). The impact of internal controls and penalties on fraud. Journal of Information Systems, 24(1), 1-21.

Bierstaker, J., Janvrin, D., \& Lowe, D. J. (2007). An examination of factors associated with the type and number of internal control documentation formats. Advances in Accounting, 23(07), 31-48.

Bower, J. B., \& Schlosser, R. E. (1965). Internal control-Its true nature. The Accounting Review, (April), 338-345. 
Brown, N. C., Pott, C., \& Wömpener, A. (2014). The effect of internal control and risk management regulation on earnings quality: Evidence from Germany. Journal of Accounting and Public Policy, 33(1), 1-31.

Chalmers, K., Hay, D., \& Khlif, H. (2018). Internal control in accounting research: A review. Journal of Accounting Literature, 42, 80-103.

Chang, J. C., \& Sun, H. L. (2010). Does the disclosure of corporate governance structures affect firms' earnings quality? Review of Accounting and Finance, 9(3), 212-243.

Cheng, M., Dhaliwal, D., \& Zhang, Y. (2013). Does investment efficiency improve after the disclosure of material weaknesses in internal control over financial reporting? Journal of Accounting and Economics, 56(1), $1-18$.

Clinton, S. B., Pinello, A. S., \& Skaife, H. A. (2014). The implications of ineffective internal control and SOX 404 reporting for financial analysts. Journal of Accounting and Public Policy, 33(4), 303-327.

COSO. (2013). Internal Control-Integrated Framework: Executive Summary.

Defond, M. L., \& Lennox, C. S. (2016). Do PCAOB inspections improve the quality of internal control audits? Journal of Accounting Research, 55(3), 591-627.

Deumes, R., \& Knechel, W. R. (2008). Economic incentives for voluntary reporting on internal risk management and control systems [Electronic Version]. Auditing: A Journal of Practice \& Theory, 27(1), 35-66.

Doyle, J., Ge, W., \& McVay, S. (2007). Determinants of weaknesses in internal control over financial reporting. Journal of Accounting and Economics, 44(1-2), 193-223.

Doyle, J. T., Ge, W., \& McVay, S. (2007). Accruals quality and internal control over financial reporting. The Accounting Review, 82(5), $1141-1170$. 
Dumay, J. (2014). 15 years of the journal of intellectual capital and counting: A manifesto for transformational IC research. Journal of Intellectual Capital, 15(1), 2-37.

Gong, G., Ke, B., \& Yu, Y. (2013). Home country investor protection, ownership structure and cross-listed firms' compliance with SOXmandated internal control deficiency disclosure. Contemporary Accounting Research, 30(4), 1-59.

Guthrie, J., Ricceri, F., \& Dumay, J. (2012). Reflections and projections : A decade of intellectual capital accounting research. The British Accounting Review, 44(2), 68-82.

Hermanson, H. M. (2000). An analysis of the demand for reporting on internal control. Accounting Horizons, 14(3), 325-341.

Hoitash, U., Hoitash, R., \& Bedard, J. C. (2009). Corporate governance and internal control over financial reporting: A comparison of regulatory regimes. The Accounting Review, 84(3), 839-867.

Jamaluddin, A. (2015). Management accounting change: A case study in Australian vocational education providers. University of Sydney.

Jokipii, A. (2009). Determinants and consequences of internal control in firms: A contingency theory based analysis. Journal of Management \& Governance, 14(2), 115-144.

KPMG. (2013). Malaysia Fraud, Bribery and Corruption Survey, 1-72.

Leng, J. (2011). Internal control disclosure and corporate governance: Empirical research from Chinese listed companies. Technology and Investment, 02(04), 286-294.

Li, C., Lim, J.-H., \& Wang, Q. (2007). Internal and external influences on IT control governance. International Journal of Accounting Information Systems, 8(4), 225-239. 
Lopez, T. J., Vandervelde, S. D., \& Wu, Y. (2009). Investor perceptions of an auditor's adverse internal control opinion. Journal of Accounting and Public Policy, 28, 231-250.

Massaro, M., Dumay, J., \& Guthrie, J. (2016). On the shoulders of giants: undertaking a structured literature review in accounting. Accounting, Auditing and Accountability Journal, 29(5), 767-801.

Murphy, D. L., \& Tibbs, S. L. (2010). Internal controls and the cost of fraud: An empirical investigation. Journal of Corporate Treasury Management, 3(2), 127-132.

Rezaee, Z. (1995). What the COSO report means for internal auditors. Managerial Auditing Journal, 10(6), 5-9.

Schneider, A., Gramling, A. A., Hermanson, D. R., \& Ye, Z. S. (2009). A review of academic literature on internal control reporting under SOX. Journal of Accounting Literature, 28, 1-46.

Schroeder, J. H., \& Shepardson, M. L. (2016). Do SOX 404 control audits and management assessments improve overall internal control system quality? The Accounting Review, 91(5), 1513-1541.

Seetharaman, A., Senthilvelmurugan, M., \& Periyanayagam, R. (2004). Anatomy of computer accounting frauds. Managerial Auditing Journal, 19(8), 1055-1072.

Singer, Z., \& You, H. (2011). The effect of Section 404 of the SarbanesOxley Act on earnings quality. Journal of Accounting, Auditing \& Finance, 26(3), 556-589.

Skaife, H. A., Veenman, D., \& Wangerin, D. (2013). Internal control over financial reporting and managerial rent extraction: Evidence from the profitability of insider trading. Journal of Accounting and Economics, 55(1), 91-110.

Voon, M., Voon, S., \& Puah, C. (2008). An empirical analysis of the determinants of corporate crime in Malaysia. International Applied Economics and Management Letters, 1(1), 13-17. 